\title{
Does Differentiation by Certified Raw Wood Change the Average Price at the Tama Roundwood Market Center in Tokyo, Japan?
}

\author{
Shohei Kameyama ${ }^{1,+}$ and Katsuaki Sugiura ${ }^{2, *,+}$ (D) \\ 1 Graduate School of Bioresource Sciences, Nihon University, Fujisawa 252-0880, Japan; \\ kameyama.shohei.0110@gmail.com \\ 2 College of Bioresource Sciences, Nihon University, Fujisawa 252-0880, Japan \\ * Correspondence: sugiura.katsuaki@nihon-u.ac.jp; Tel.: +81-466-84-3670 \\ + Shohei Kameyama and Katsuaki Sugiura equally contributed as first authors.
}

check for updates

Citation: Kameyama, S.; Sugiura, K. Does Differentiation by Certified Raw Wood Change the Average Price at the Tama Roundwood Market Center in Tokyo, Japan?. Forests 2021, 12, 264. https://doi.org/10.3390/f12030264

Academic Editor:

Venceslas Goudiaby

Received: 26 January 2021

Accepted: 21 February 2021

Published: 25 February 2021

Publisher's Note: MDPI stays neutral with regard to jurisdictional claims in published maps and institutional affiliations.

Copyright: (c) 2021 by the authors. Licensee MDPI, Basel, Switzerland. This article is an open access article distributed under the terms and conditions of the Creative Commons Attribution (CC BY) license (https:// creativecommons.org/licenses/by/ $4.0 /)$.

\begin{abstract}
It is important to understand price premiums related to certified raw wood to predict the future of forest certifications from the perspective of forestry enterprises. We focused on identifying the trading roundwood market data in the economic center of power in Tokyo. This study aimed to clarify Tama-certified raw wood prices under the local area certification scheme, forest-certified raw wood prices, and the handling volumes at the Tama Roundwood Market Center in Tokyo. Sales details of the Tama Roundwood Market Center were used to identify the handling volumes, Tama-certified raw wood prices, and FSC (Forest Stewardship Council) or SGEC (Japan-specific Sustainable Green Ecosystem Council)-certified raw wood prices. The FSC and SGEC have operated from the center since 2016. Data were collected from the 2006-2018 fiscal years. Our results showed that the volume of raw wood handled increased due to the regeneration-cutting project conducted by the Tokyo Metropolitan Government. On the other hand, there was no price premium for Tamacertified raw wood under the local certification scheme or for FSC- or SGEC-certified raw wood. Price premiums for forest certifications are necessary for ongoing sustainable forest management. There is a need to increase consumer awareness of forest certifications and to differentiate quality certifications further, and these would likely create price premiums.
\end{abstract}

Keywords: certified wood; Forest Stewardship Council (FSC); Sustainable Green Ecosystem Council (SGEC); forest certification; sustainable forest management; raw wood; roundwood market; price premium

\section{Introduction}

A Forest Certification Scheme is a mechanism for certifying sustainable forest management. Global certification schemes include the Forest Stewardship Council (FSC) and the Programme for the Endorsement of Forest Certification (PEFC). The FSC, founded in 1993 [1], has developed a global certification process to support and verify environmentally, socially, and economically beneficial forest management practices. The PEFC was established in 1999, and the organization was initially known as Pan European Forest Certification (PEFC) in the European region [2]. In 2003, the name was changed to Programme for the Endorsement of Forest Certification due to a process of internationalization with the addition of non-European countries such as Australia and Chile [2]. The PEFC is expanding its role as an international certification organization that recognizes the certification systems of countries around the world, including countries in the Asian region [2].

On the other hand, national and regional certification schemes exist. The Japanese forest certification scheme has a global FSC and Japan-specific Sustainable Green Ecosystem Council (SGEC). Interest in forest certification has grown in Japan since Hayami Forest first obtained an FSC forest management certification in 2000 [3]. In 2003, the Japanese version 
of the SGEC forest certification was established. The SGEC certification is a version of the FSC system that was specifically developed for forest certification in Japan. The purpose of establishing the SGEC certification system was to create a framework for forest certification tailored to the specific characteristics of Japanese forests and forestry.

By 2006, the SGEC area exceeded that of the FSC; in 2018, the FSC area was 410,000 ha, whereas the SGEC area was 1.89 million ha, with a fourfold difference [4]. The numbers of FSC- and SGEC-certified forest enterprises also increased, and, as of May 2014, FSC had 35 certified forest enterprises, and SGEC had 92. FSC- and SGEC-certified forests in Japan have primarily increased in active timber production regions [5].

The SGEC received mutual recognition with PEFC in 2016. However, compared to other countries, Japan's forest certification acquisition rate is not high. The proportion of certified forest area in Japan with international certifications (FSC and PEFC) was as low as $8 \%$ in 2018 [4]. In contrast, more than $80 \%$ of Finland's, Germany's, and Sweden's forested areas are certified [4]. Approximately 70\% of Austria's forested areas, 50\% of Canada's, and $15 \%$ of the United States' forested areas are certified [4]. The reason for the low certified forest area might be because the premium price in the Japanese market is not attached to the labor and cost of certification acquisition.

Therefore, in this study, we focused on the Tama Roundwood Market Center, which is the only raw market in Tokyo. At the roundwood center, certified materials known as Tama-certified materials, SGEC materials, and FSC materials are handled. Japanese raw wood prices are falling compared to the past [4]; however, there is a notable variation in raw wood prices, and it is important to analyze whether there is a premium price for wood from sustainably managed forests. If certified raw wood commands a higher price than uncertified materials, then more forestry enterprises may become certified. Thus, the analysis of raw wood prices affects not only economic issues but also sustainable forest management.

Previous studies have analyzed corrective action requests (CARs) in certification assessments, and studies have investigated certificate holders' experiences and CARs related to FSC and SGEC certification in Japan [6-11]. The studies revealed that the most common CARs in FSC principles or SGEC standards for forest management in Japan are as follows: management planning, environmental impact assessments, and monitoring. However, the level of forest management in Japan was higher than in other Asian countries based on the number of CARs in global FSC certifications [12]. Regardless of the variations in the numbers of CARs issued, obtaining forest management certifications should help improve forest management, whether the forest is FSC- or SGEC-certified. In addition, there are reports analyzing the CARs of forests in other countries in an FSC study [13-16]. There are also some studies that have analyzed the price premium of certified wood in Europe, North America, Bolivia, Malaysia and Japan [17-22].

To the best of our knowledge, few studies have investigated the price differences between certified and uncertified raw wood in roundwood markets, even though forest certification is an important issue that should be actively discussed in Japan since it is the world's leading wood-importing country [4], and only a few studies have been conducted on forest certification in Japan.

It is also important to understand any price premiums related to certified raw wood to predict the future of Japan's forest certification system from the perspective of the forestry enterprises that are obtaining certification. The handling volume and price trends of forestcertified logs are important, not only in Japan but also internationally. To improve our understanding in this regard, it is necessary to identify the trading roundwood market data in the international economic center of power in Tokyo.

In the Tama region of Tokyo, there is a "Raw wood from Tama" certification scheme, and Tama-certified wood from the Tama region is distributed. Therefore, the Tama Roundwood Market Center handles uncertified wood and Tama-, FSC-, and SGEC-certified wood.

Therefore, this study aimed to clarify the prices of uncertified raw wood, Tamacertified wood, FSC- and SGEC-certified raw wood and their handling volumes in the 
Tama Roundwood Market Center, Tokyo. Through an analysis of market trading data, the present study helps consider the future of raw wood branding strategies including various certification schemes in countries, including Japan, and the responses they elicit.

\section{Forestry and Tama Roundwood Market Center in Tokyo}

The following is an overview of the forestry and Tama roundwood market center, based on the references in "Forests and Forestry in Tokyo" [23]. Forests cover approximately $40 \%$ of the total area in Tokyo and are distributed mainly in Tama and island areas. Forest in Tokyo is located close to the city residents and has many uses. One of these is the supply of resources such as raw wood, which contributes to the lives of Tokyo residents. However, in Tokyo, the forestry industry, in general, has stagnated in terms of logging and afforestation due to a decline in profitability caused by a reduction in raw wood prices. Therefore, problems such as the loss of young forests and an increase in aged forests, bare land on the forest floor, and an increase in cedar pollen scattering arose. Many people suffer from allergies caused by Japanese cedar, or sugi (Cryptomeria japonica (L. f.) D. Don), pollen in Japan.

The Tokyo Metropolitan Government implemented the "Sugi pollen emission source countermeasure project" over 10 years ago from fiscal 2006. This project involved cutting down sugi forests and planting sugi varieties with little pollen to reduce the pollen count and regenerate forestry. This project was funded by grants and subsidies from the Tokyo Metropolitan Government. The Tokyo Metropolitan Agriculture, Forestry and Fisheries Promotion Foundation purchased standing trees from forest owners in Tama, and various activities from regeneration cutting to selling raw wood sales were performed using funds and subsidies from the Tokyo Metropolitan Government. In addition, the expenses necessary for planting and tending received a subsidy. The business framework was restructured, and the "Forest Sustainable Promotion Project" was initiated with a new 10-year plan from fiscal 2015. This project involves logging the sugi and hinoki (Chamaecyparis obtuse (Sieb. et Zucc.) Endl.) that emit a large amount of pollen, supplying Tama with raw wood, and supporting the planting and raising of sugi and hinoki with less pollen after logging, as part of allergy countermeasures [24]. Therefore, no major changes were enacted compared with the previous project. In this study, the forests harvested by these projects were designated as "regeneration cutting project forests."

The Tama area has a "Raw wood from Tama" certification scheme, which certifies that it is raw wood supplied from appropriately managed forests [25]. The primary target forests for the certification are regeneration cutting project forests, forests with forest management plans approved by the government, and forests covered for public works [25]. These forests are appropriately managed. Tama-certified wood must be handled by Tama wood certification registration companies during the raw wood production and distribution process [25]. The raw wood along the path of the solid line in Figure 1 is treated as Tama-certified wood. Raw wood in the path indicated by the dashed line is not treated as Tama-certified wood. The number of registered enterprises is 76 forest owners, 38 material producers, one roundwood market, and 34 sawmills (as of April 2018) [26]. The only roundwood market in Tokyo is the Tama Roundwood Market Center [26]. This center is an important base for raw wood distribution in the Tama area. Raw wood is sold at the Tama Roundwood Market Center by auction, with logs stacked by shipper, species, diameter, and length. 


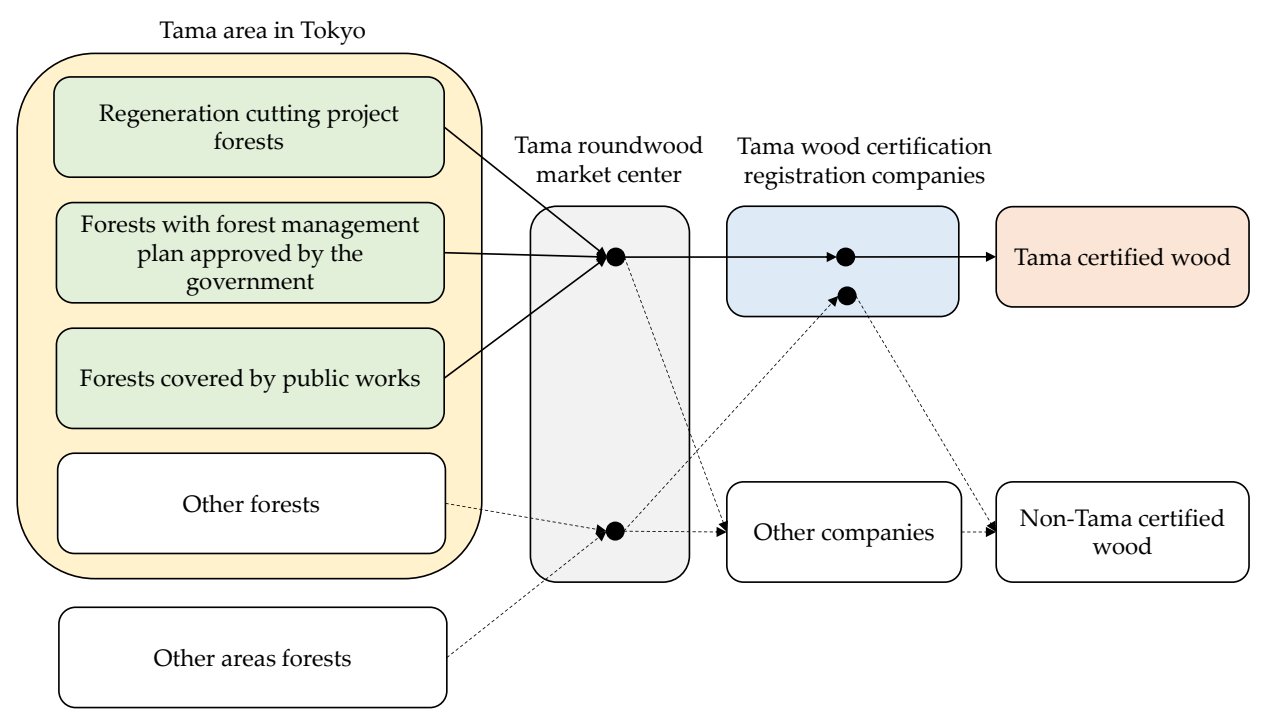

Figure 1. Structure of the Tama certification scheme. The raw wood along the path of the solid line is treated as Tama-certified wood. Raw wood in the path indicated by the dashed line is not treated as Tama-certified wood.

The main condition for procuring timber for the Tokyo 2020 Olympic and Paralympic Games was using wood produced from sustainably managed forests (certified wood) [27]. Therefore, the Tokyo Metropolitan Government provided support to forestry enterprises and wood processing distributors in Tokyo for the full cost of obtaining and maintaining forest management (FM) certifications and chain of custody $(\mathrm{CoC})$ certifications from the fiscal years 2016 to 2020 [27]. The Tama Roundwood Market Center also obtained SGEC CoC certification in July 2016 and FSC CoC certification in August 2016 with financial support from the Tokyo Metropolitan Government. The Tama Roundwood Market Center began handling these certified woods in August 2016. As of November 2017, there are three FSC FM-certified entities and three SGEC FM-certified entities in Tokyo forests (one entity is certified for both) [28]. Among the entities that deal with Tama-certified wood, there are six FSC CoC-certified entities and 17 SGEC CoC-certified entities (five entities are certified for both) [28].

\section{Materials and Methods}

Detailed sales data for the twice-monthly market held at the Tama Lumber Center were obtained. The data recorded the species, length, diameter, raw wood volume, price, and whether or not the raw wood was Tama-certified and forest-certified for each unit traded. Sales details of the Tama Roundwood Market Center were used to identify the handling volumes and prices of FSC or SGEC certified raw wood and Tama-certified raw wood. Data were analyzed from the fiscal year (FY) 2006 to FY 2018. The items were analyzed as the amount of timber handled, the price of raw wood, the presence or absence of FSC or SGEC certifications, the presence or absence of Tama certifications, and tree species.

As for the volume and price of the handled raw wood, the price depends on the diameter and length of the wood. Raw wood of various sizes is handled at the Tama Roundwood Market Center. This study did not consider the differences in size since all raw wood handled at the center has commercial value. Therefore, we analyzed the volume and average price of logs handled in the center.

The Tama Roundwood Market Center has been handling FSC- and SGEC-certified wood since FY 2016, and most of the Tama-certified wood is FSC and SGEC certified (double certification of Tama-certified wood and FSC- or SGEC-certified wood). Therefore, the price difference between Tama-certified and uncertified wood was analyzed using data from FY 2006 to FY 2015, while the price difference between FSC and SGEC certified wood was analyzed from FY 2016 to FY 2018. In this study, both the FSC- and the SGECcertified wood (double forest-certified wood) were treated as FSC-certified wood because 
the FSC certification scheme is considered a more strictly regulated system than other forest certification schemes in the Canadian case [29]. In some cases, some of them will be double or triple certified. In this study, the order of priority in Figure 2 is given to FSC- > SGEC$>$ Tama-certified wood for the analysis. For example, if raw wood was FSC-, SGEC-, and Tama-triple-certified wood, then it was treated as FSC certified, and if it was SGEC- and Tama-double-certified wood, then it was treated as SGEC certified. The raw wood was classified as FSC-, SGEC-, and Tama-certified and uncertified wood in addition to being classified by species, such as sugi, hinoki, and other conifers.

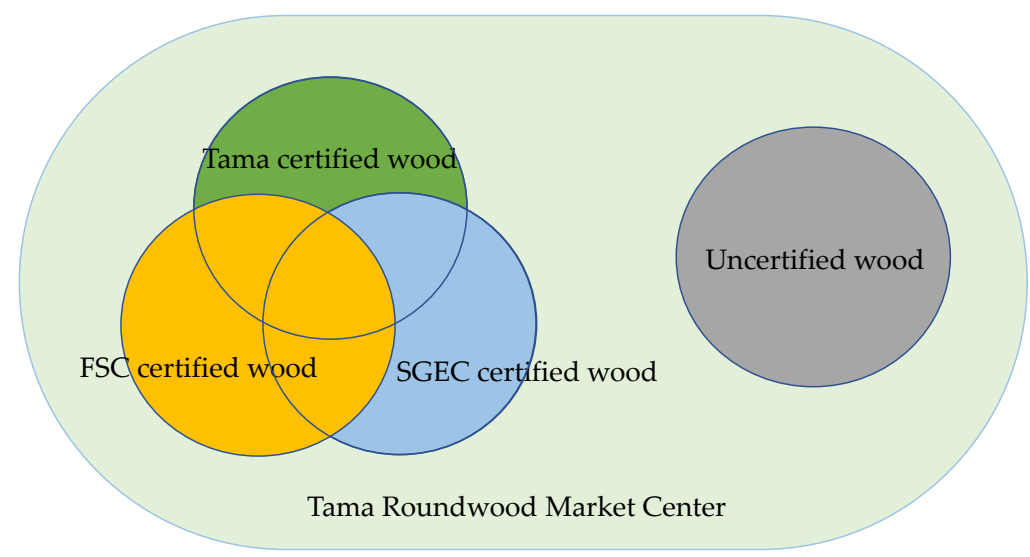

Figure 2. Treatment of double- and triple-certified raw wood.

We conducted an exact test between the certified and uncertified raw wood prices (Rviewer software, Data Science Institute, Tokyo, Japan). Differences were deemed statistically significant at $p<0.05$. Comparisons of the price of Tama-certified raw wood, and non-Tama-certified raw wood were performed using the Student's $t$-test. A one-way analysis of variance (ANOVA) was used to compare the means among groups (the price of FSC certified wood, SGEC certified wood, Tama-certified raw wood, and uncertified wood). If the ANOVA was significant, then the Bonferroni/Dunn procedure was used as a post hoc test.

In this study, the transaction price of raw wood is expressed in the reserve currency US dollars (USD). One US dollar is converted to 105 Japanese yen with reference to the exchange rate as of November 2020.

\section{Results}

4.1. Volume and Price of the Raw Wood Handled by the Tama Roundwood Market Center

The volume of raw wood handled by the Tama Roundwood Market Center increased from $8904 \mathrm{~m}^{3}$ in FY 2006 to 17,730 $\mathrm{m}^{3}$ in FY 2012, but the volume of raw wood handled after that was around 16,500 $\mathrm{m}^{3}$ and continued to increase and decrease until FY 2018 (Figure 3). The volume of raw wood handled by the Tama Roundwood Market Center before the regeneration cutting project had a downward trend from FY 1994 to FY 2005 [30-32]. After the project, the volume increased. The majority of the raw wood species handled were sugi, followed by hinoki. Other coniferous wood and hardwood were handled less frequently, as shown in Figure 3. 


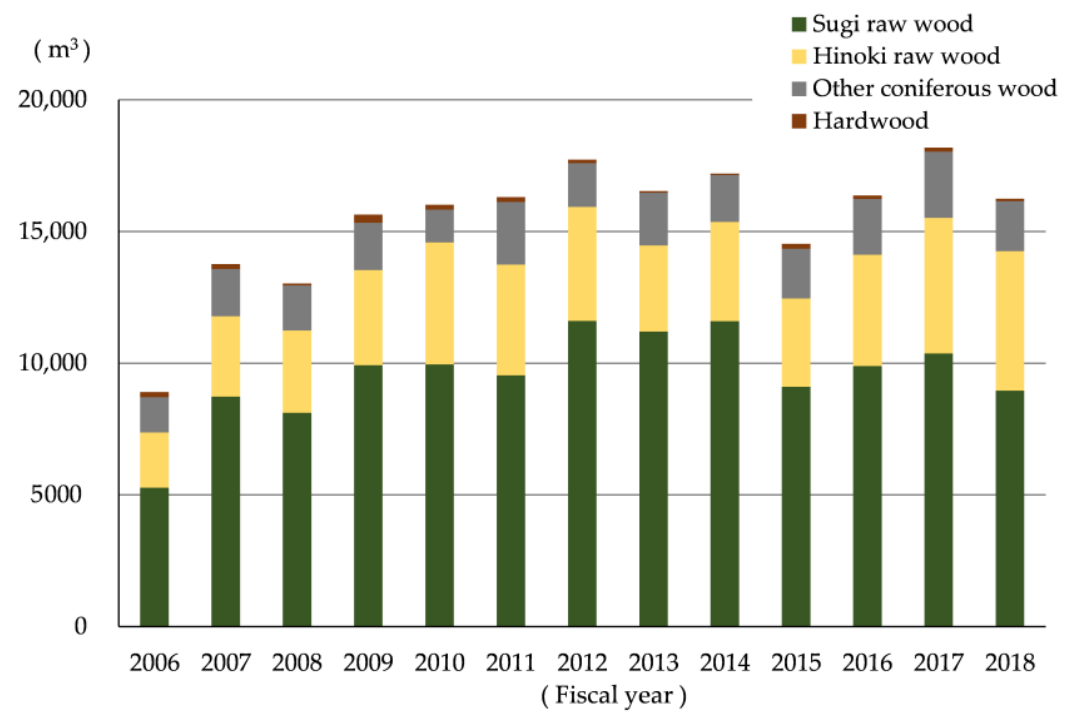

Figure 3. Handling volume of raw wood by tree type at Tama Roundwood Market Center.

The volume of raw wood handled by the Tama Roundwood Market Center and the percentage of raw wood from the regeneration cutting project in FY 2006, when the regeneration cutting project was launched, was lower than in other years. Subsequently, the percentage of raw wood from the regeneration cutting project gradually increased from 2011; the percentage was between approximately $60 \%$ and $70 \%$, as shown in Figure 4 . The volume of raw wood handled by the Tama Roundwood Market Center tended to be higher when the percentage of raw wood from the regeneration cutting project was higher (Figure 4).

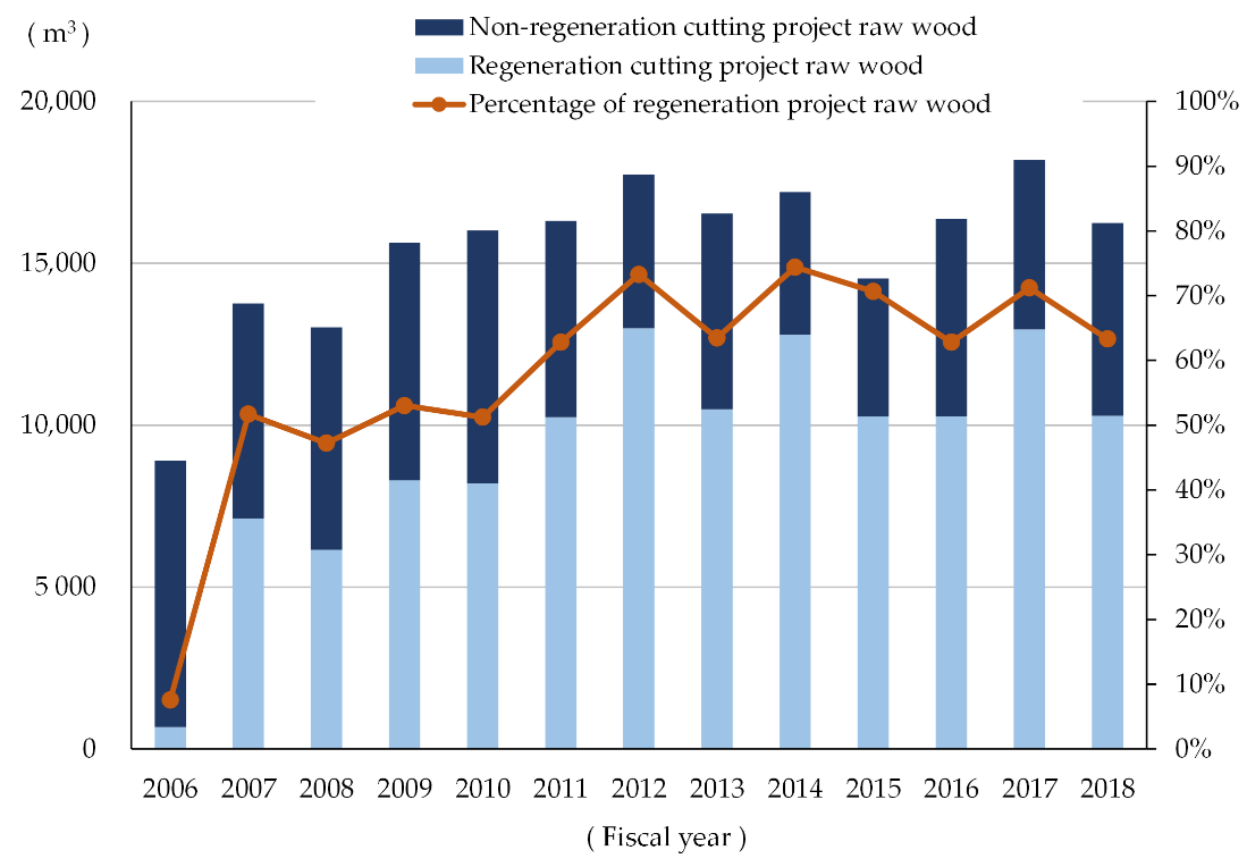

Figure 4. Handling volume of raw wood from the regeneration cutting project at Tama Roundwood Market Center.

The average prices handled at the Tama Roundwood Market Center, and the average prices by type of raw wood are shown in Figure 5. Hardwoods were excluded because of the low volume handled. The average price of all the raw wood at the center (dashed line in Figure 5) decreased since FY 2006 but increased in FY 2018. The highest price in 
FY 2006 was approximately $142 \mathrm{USD} / \mathrm{m}^{3}$, while the lowest price in FY 2017 was around $101 \mathrm{USD} / \mathrm{m}^{3}$. The price difference between the two was approximately $40 \mathrm{USD} / \mathrm{m}^{3}$.

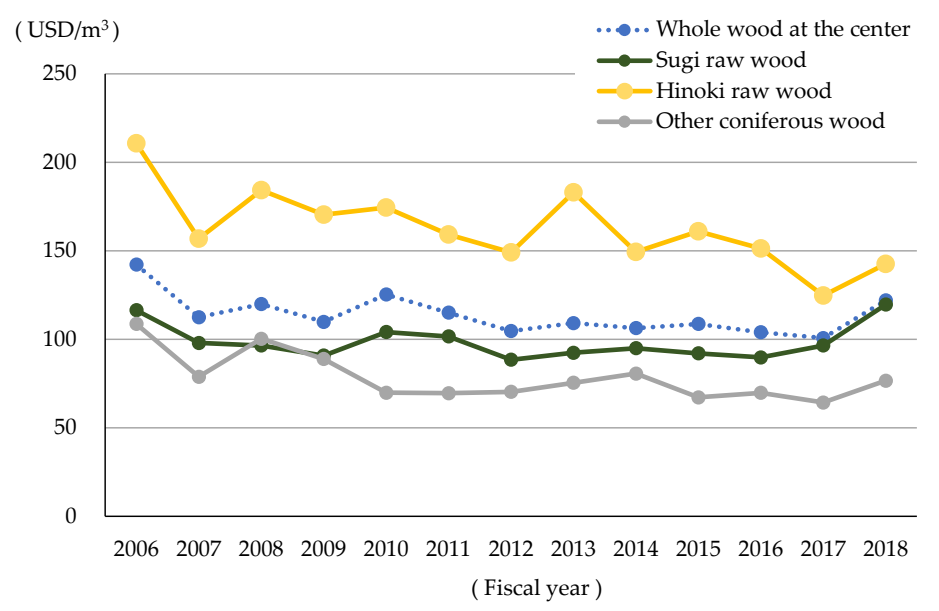

Figure 5. Average price $\left(\mathrm{USD} / \mathrm{m}^{3}\right.$ ) of raw wood by tree type at Tama Roundwood Market Center.

Based on tree type, hinoki raw wood was the most expensive, at approximately $211 \mathrm{USD} / \mathrm{m}^{3}$ in FY 2006. After this, prices decreased, ranging from $124 \mathrm{USD} / \mathrm{m}^{3}$ to $184 \mathrm{USD} / \mathrm{m}^{3}$, with an average price of around $163 \mathrm{USD} / \mathrm{m}^{3}$. Sugi raw wood, which is handled in large volumes, reached its highest price of $120 \mathrm{USD} / \mathrm{m}^{3}$ in FY 2018. Sugi raw wood was traded between a range of approximately $89 \mathrm{USD} / \mathrm{m}^{3}$ to $120 \mathrm{USD} / \mathrm{m}^{3}$, with an average price of $99 \mathrm{USD} / \mathrm{m}^{3}$. Other coniferous wood was traded at an average price of around $79 \mathrm{USD} / \mathrm{m}^{3}$.

The overall trend is that the price of raw wood decreases as the volume of raw wood handled increases, and increases as the volume of raw wood handled decreases. In addition, some logs in the regeneration cutting project are affected by boring insects [30]. Before the regeneration cutting project, the amount of raw wood handled by the Tama Roundwood Market Center in the summer and autumn seasons was small due to damage by these boring insects [33]. However, the regeneration cutting project is susceptible to impacts from boring insects because raw wood is cut down in inappropriate seasons and left on the timber yard for long periods [32]. Buyers are reluctant to purchase logs affected by insects, leading to lower market prices [34]. Additionally, in some cases, delayed thinning of the forest results in regeneration cutting, and the percentage of defective trees with poor growth and morphology is high in the regeneration cutting projects [31].

\subsection{Volume and Price of Tama-Certified Raw Wood Handled at Tama Roundwood Market Center}

In FY 2006, the amount of Tama-certified wood handled by the raw wood from the Tama certification scheme was approximately $20 \%$ of the center's total volume, but in FY 2007 , the amount handled exceeded $50 \%$, as shown in Figure 6 . Since then, the percentage of Tama-certified raw wood has increased steadily, exceeding 70\% in FY 2012 and over $80 \%$ in FY 2018. Before the regeneration cutting project, $50 \%$ of the raw wood handled by the Tama Roundwood Market Center came from the Tama area, with the remaining 50\% coming from other regions [35]. The percentage of raw wood from the Tama area increased due to the regeneration cutting project. The percentage of Tama-certified sugi raw wood has been higher than that of hinoki and other coniferous wood since FY 2011. In particular, more than $80 \%$ of the sugi raw wood from FY 2014 was handled as Tama-certified raw wood, as shown in Figure 6. 


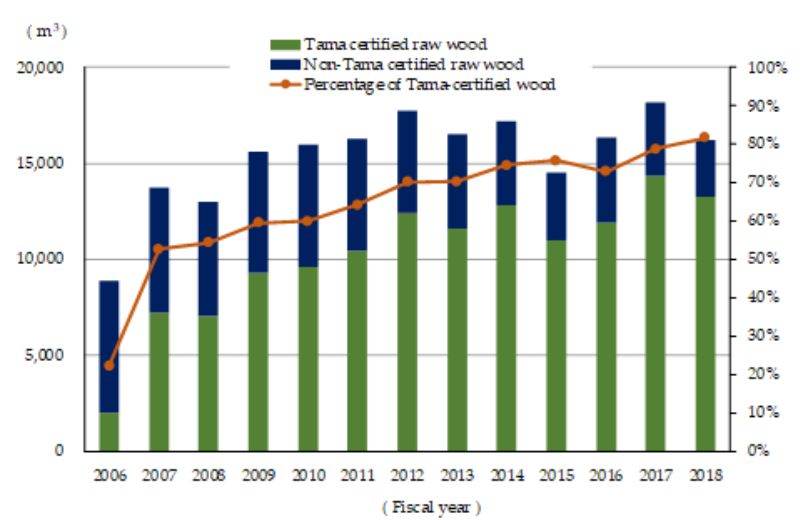

(a)

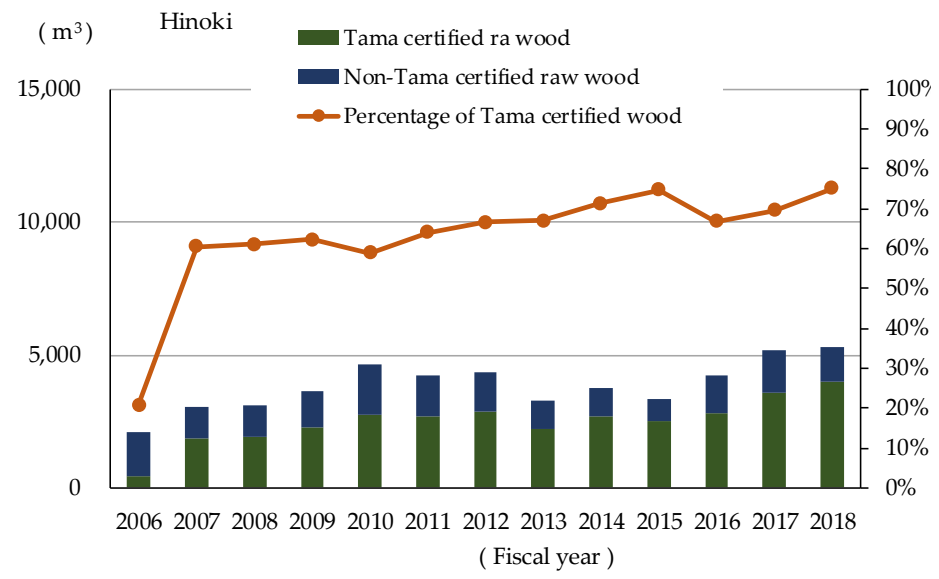

(c)

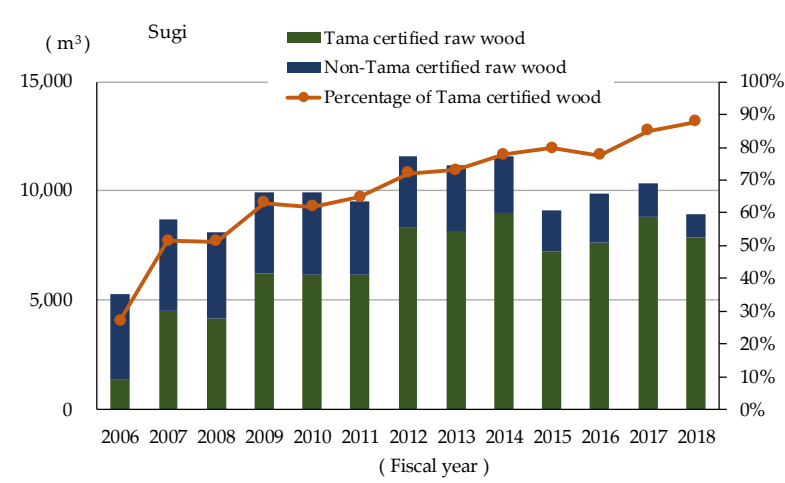

(b)

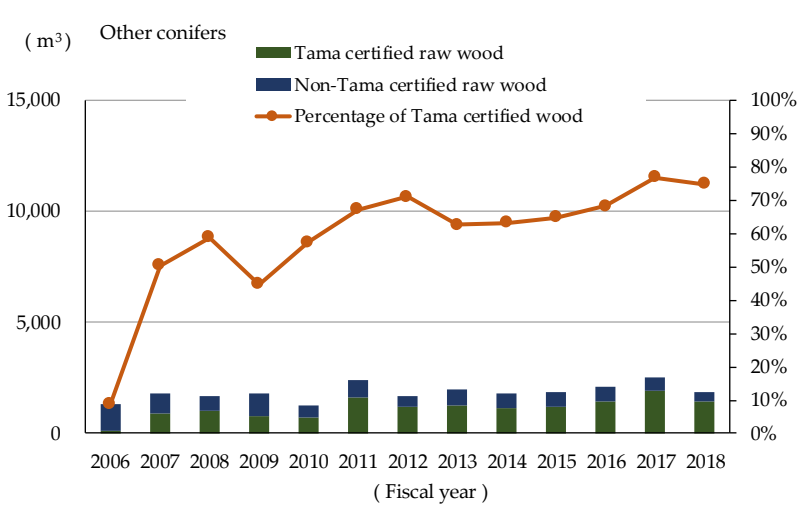

(d)

Figure 6. Handling volume of Tama-certified raw wood at Tama Roundwood Market Center: (a) handling volume of the entire center; (b) handling volume of sugi; (c) handling volume of hinoki; (d) handling volume of other conifers.

Statistical differences in the prices of Tama-certified raw wood and non-Tama-certified raw wood were confirmed by the Student's $t$-test (two-sided) from 2006 to 2015 before the handling of forest-certified wood. There was no statistical significance for sugi ( $p=0.53)$ and hinoki $(p=0.81)$, while non-Tama-certified other conifer wood $(p=0.00043)$ was statistically significant in Figure 7. The price transition of sugi and hinoki raw wood was the same for both Tama-certified and non-Tama-certified raw wood in Figure 7. On the other hand, the prices of other coniferous raw wood tended to be higher for non-Tama-certified raw wood.

\subsection{Volume and Price of FSC and SGEC Raw Wood Handled at Tama Roundwood Market Center}

The Tama Roundwood Market Center has been handling forest-certified raw wood since FY 2016 due to the acquisition of FSC and SGEC CoC certifications. In some cases, some raw wood is both FSC- and SGEC-certified. In this study, both the FSC- and the SGECcertified wood were treated as FSC-certified wood because the FSC certification scheme is considered a more strictly regulated system than other forest certification schemes [29]. The categories are FSC-, SGEC-, and Tama-certified wood from the top to the bottom. Whether double or triple certified, it was treated as the most highly ranked category of certified wood. 


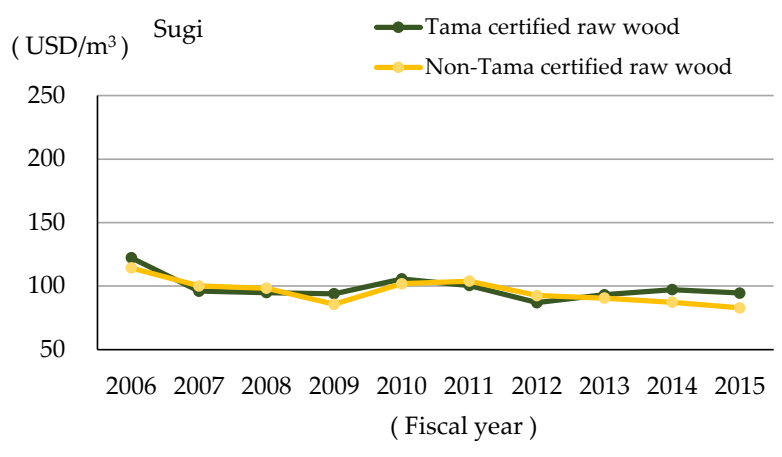

(a)

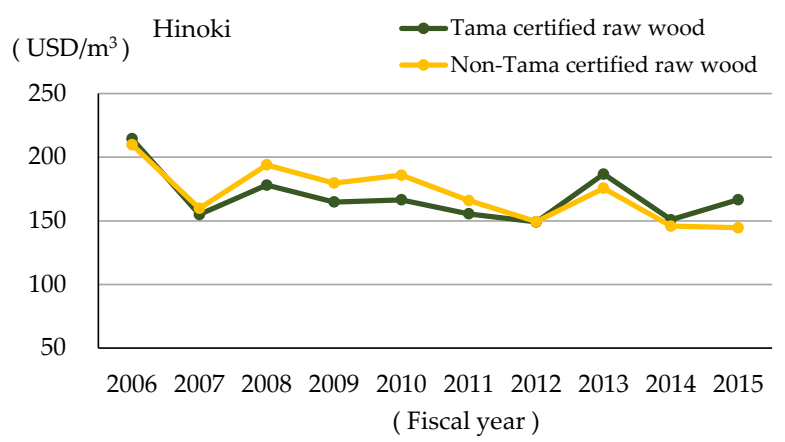

(b)

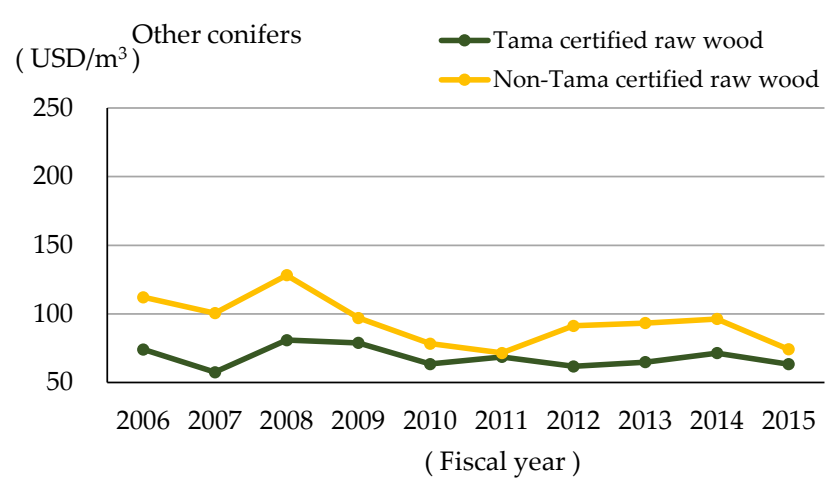

(c)

Figure 7. Average price $\left(\mathrm{USD} / \mathrm{m}^{3}\right)$ of Tama-certified raw wood by tree type at Tama Roundwood Market Center: (a) average price of sugi; (b) average price of hinoki; (c) average price of other conifers.

The percentage of forest-certified wood handled was $40 \%$ of about $6700 \mathrm{~m}^{3}$ in 2016 , while the percentage of certified wood from 2017 was more than $70 \%$ (more than $11,500 \mathrm{~m}^{3}$ ) (Figure 8). In terms of the type of certification, most of the raw wood was SGEC-certified, and a lesser amount was FSC-certified.

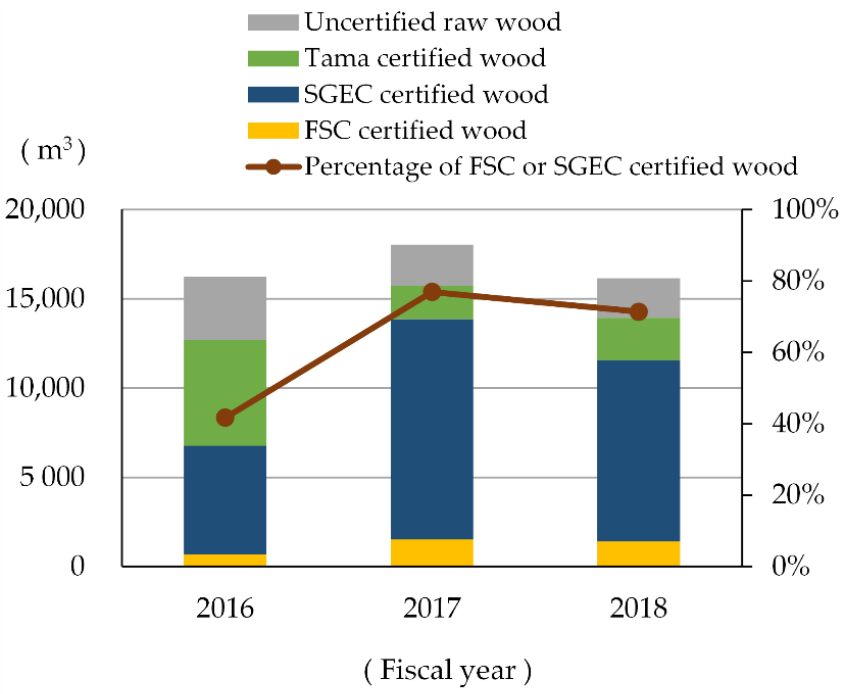

Figure 8. Handling volume of FSC- and SGEC-certified raw wood at Tama Roundwood Market Center.

There was no difference in the percentage of forest-certified raw wood by tree species. The percentage of certified raw wood of any tree species was around $40 \%$ in FY $2016,75 \%$ in FY 2017, and 70\% in FY 2018 (Figure 9). In the three years from FY2016 to FY2018, FSC-certified wood was $3618 \mathrm{~m}^{3}$, of which $3292 \mathrm{~m}^{3}$ was in the form of logs that were also 
Tama certified. Therefore, about $91 \%$ of the FSC-certified wood was also Tama certified. In addition, the total number of SGEC-certified materials over the three years was $28,626 \mathrm{~m}^{3}$, of which $26,112 \mathrm{~m}^{3}$ was in the form of logs that were also Tama certified. Therefore, about $91 \%$ of SGEC-certified wood was also Tama certified. There was $38 \mathrm{~m}^{3}$ of triple-certified raw wood in the three years, which is only a small amount.

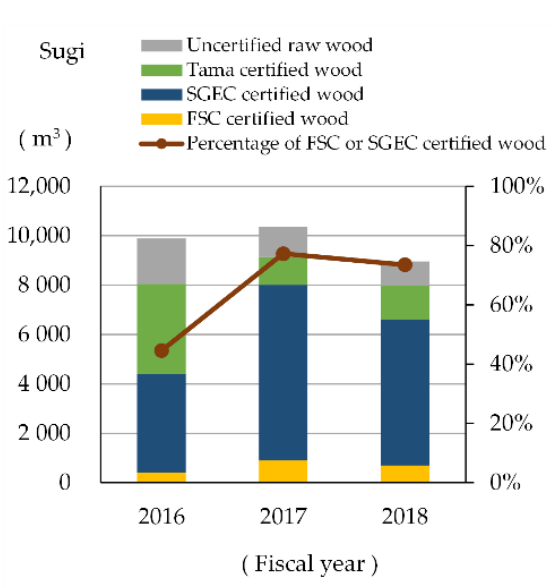

(a)

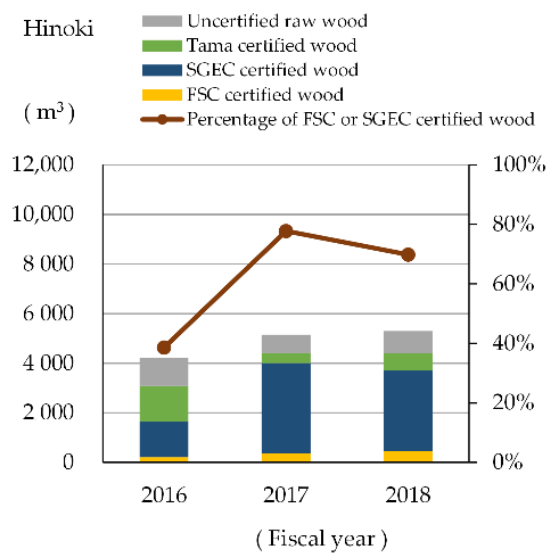

(c)

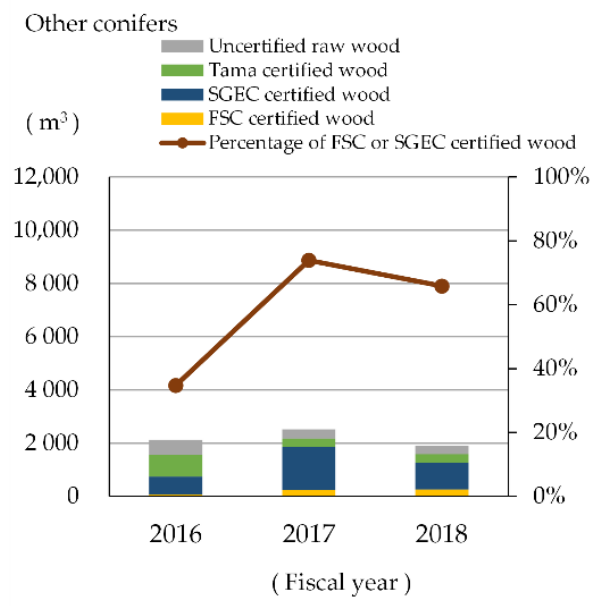

(e)

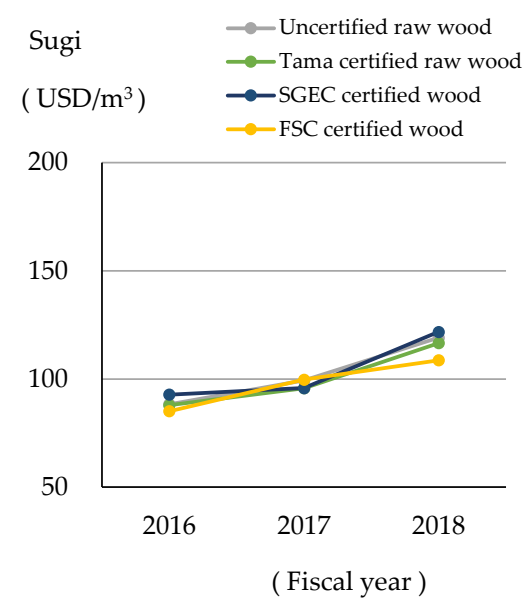

(b)

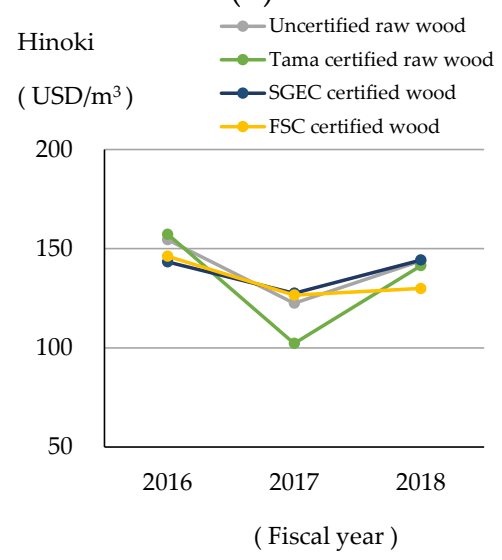

(d)

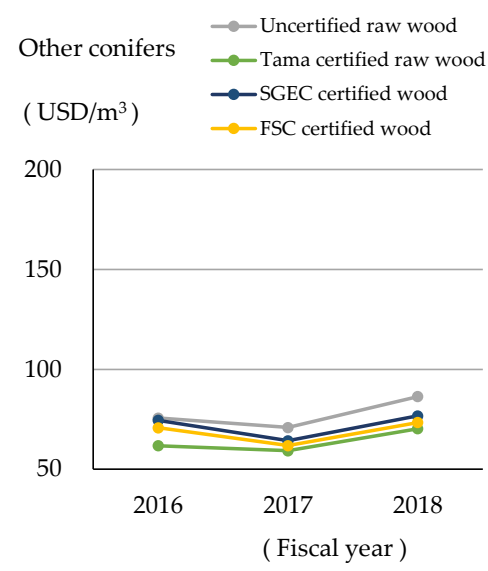

(f)

Figure 9. Handling volume and average price $\left(\mathrm{USD} / \mathrm{m}^{3}\right.$ ) of FSC- and SGEC-certified wood by tree type at Tama Roundwood Market Center. (a) handling volume of sugi; (b) average price of sugi; (c) handling volume of hinoki; (d) average price of hinoki; (e) handling volume of other conifers; (f) average price of other conifers. 
An analysis of the presence or absence of price premiums for forest-certified raw wood was conducted. Statistical differences in the prices of FSC-certified raw wood, SGECcertified raw wood, Tama-certified wood, and uncertified raw wood were confirmed by an ANOVA test. There was no statistical significance for sugi $(p=0.97)$, hinoki $(p=0.96)$, and other conifers $(p=0.15)$. Since the ANOVA was not significant, the Bonferroni/Dunn procedure was not used as a post hoc test. In other words, there was no statistical difference in the average price of raw wood with or without forest certification in terms of tree type, as shown in Figure 9. The forest-certified raw wood traded at the Tama Roundwood Market Center did not have a price premium and was traded at the same price as uncertified raw wood. This study's results are similar to those of other studies, which found that certified woods from Europe, North America, and Japan generally have low price premiums [17-20].

Since the data presented here are comparisons based on averages, there is a possibility that some raw wood is included the good or poor raw wood. Table 1 shows the maximum, minimum, median, and standard deviation of prices. As a result, there was a difference in the maximum price, but it was not high because of the certified wood.

Table 1. Maximum, minimum, median, and standard deviation price of certified and uncertified wood by tree type at Tama Roundwood Market Center.

\begin{tabular}{|c|c|c|c|c|c|c|c|c|c|c|c|c|c|c|c|c|c|}
\hline \multirow{2}{*}{$\begin{array}{l}\text { Tree } \\
\text { Type }\end{array}$} & \multirow{2}{*}{$\begin{array}{l}\text { Fiscal } \\
\text { Year }\end{array}$} & \multicolumn{4}{|c|}{ FSC Certified Wood (USD/m³) } & \multicolumn{4}{|c|}{ SGEC Certified Wood (USD/m³) } & \multicolumn{4}{|c|}{ Tama Certified Wood (USD/m ${ }^{3}$ ) } & \multicolumn{4}{|c|}{ Uncertified Wood (USD/m³) } \\
\hline & & Max. & Min. & Med. & SD & Max. & Min. & Med. & SD & Max. & Min. & Med. & SD & Max. & Min. & Med. & SD \\
\hline \multirow{3}{*}{ Sugi } & 2016 & 152 & 38 & 76 & 26 & 286 & 38 & 86 & 31 & 476 & 15 & 76 & 31 & 857 & 30 & 67 & 39 \\
\hline & 2017 & 410 & 29 & 95 & 40 & 381 & 38 & 86 & 35 & 333 & 38 & 76 & 39 & 1238 & 10 & 76 & 52 \\
\hline & 2018 & 286 & 38 & 95 & 41 & 476 & 29 & 114 & 46 & 381 & 30 & 95 & 49 & 571 & 38 & 76 & 53 \\
\hline \multirow{3}{*}{ Hinoki } & 2016 & 857 & 38 & 133 & 93 & 762 & 38 & 124 & 78 & 1333 & 38 & 143 & 90 & 2857 & 29 & 95 & 128 \\
\hline & 2017 & 762 & 38 & 114 & 63 & 857 & 29 & 114 & 77 & 667 & 38 & 86 & 57 & 2095 & 10 & 95 & 107 \\
\hline & 2018 & 667 & 38 & 124 & 62 & 1905 & 30 & 124 & 115 & 952 & 38 & 105 & 85 & 1429 & 20 & 95 & 117 \\
\hline \multirow{3}{*}{$\begin{array}{l}\text { Other } \\
\text { conifers }\end{array}$} & 2016 & 99 & 40 & 66 & 17 & 286 & 26 & 67 & 25 & 171 & 26 & 57 & 20 & 286 & 29 & 60 & 36 \\
\hline & 2017 & 124 & 26 & 53 & 16 & 171 & 20 & 57 & 18 & 286 & 38 & 50 & 21 & 476 & 3 & 57 & 40 \\
\hline & 2018 & 190 & 38 & 71 & 22 & 524 & 26 & 67 & 29 & 286 & 26 & 60 & 25 & 429 & 26 & 67 & 49 \\
\hline
\end{tabular}

\section{Discussion}

The volume of logs handled at the Tama Roundwood Market Center increased from FY 2006 when the regeneration cutting project began. In other words, it is possible that the raw wood supply has increased due to the regeneration cutting project. In terms of raw wood prices, the price decreased as the supply of raw wood increased. It is likely that the price was affected by the increase in the supply of raw wood, raw wood damage from drilling, and inferior raw wood due to the regeneration cutting project.

In terms of Tama-certified raw wood, the increase in the amount of raw wood from the regeneration cutting project led to an increase in the amount of Tama-certified raw wood, contributing to a stable supply. Since Tama-certified raw wood is a certificate of origin and does not guarantee the quality, it is not priced at a premium. This suggests that it is difficult to brand wood based on proof of origin alone. The price of other conifer wood was statistically significantly higher for uncertified raw wood than for Tama-certified raw wood. This is likely due to the large amount of inferior wood from other conifers that were forcibly harvested during the regeneration cutting project and mixed with various conifer raw wood, which resulted in price differences.

Forest certification schemes provide incentives for producers to improve forestry practices and inform consumers of certain product characteristics [36]. However, there was no price difference between forest-certified and uncertified wood. In other words, buyers are not willing to pay a premium price for environmental friendliness. They started to handle certified wood from FY 2016 because they followed the policy for procuring wood for the Tokyo Olympics and Paralympics, and it is possible that they did not consider the revitalization of the local forest and forestry industry through forest certification. Japan's Ministry of Agriculture, Forestry and Fisheries showed that $66.9 \%$ of surveyed consumers reported, "I do not know the meaning of forest certification" or "I have never seen a logo" [37]. Thus, awareness of forest certification in Japan is low, and it is quite possible 
that consumers have little interest in the FSC and SGEC schemes. Furthermore, sufficient information is not available for all enterprises that manufacture and sell a product, allowing many of them to disregard environmental values [38]. On the other hand, some of the motivations for enterprises to obtain certification include ethics, corporate philosophy, and new business [39-41]. Therefore, some enterprises might acquire certification out of a sense of ethics even if there is no price premium. Another reason might be that they are acquiring the certification in order to gain new distribution channels for their raw wood. Demand for FSC-certified raw wood from the Yusuhara forest owners' cooperative in Kochi Prefecture has reportedly increased [42]. Forest enterprises with FSC certifications valued sustainable forest management relatively more than enterprises with SGEC certifications [38]. FSC audits have more conditions and recommendations than the other standards, and FSC standards require more changes in the environmental, social, economic, and management systems [29].

Although FSC and SGEC certifications have apparently improved forest management, added value in many enterprises has not been reported [43]. While countries such as Malaysia and Bolivia charge a price premium for certified wood, Japan charges almost no price premium $[21,22]$. The reason why it is difficult to get a price premium for certified wood in Japan is that there is a perception that forest management in Japan is adequate, so people might not feel the need to have certified wood. Most buyers are probably not aware of paying for environmental values. On the other hand, some enterprises with SGEC certifications saw increases in income, and some forestry enterprises reported positive economic effects [43]. Certified enterprises were generally pleased with acquiring forest certifications, although the lack of price premiums was their greatest disappointment [44]. In the future, it will be necessary to clarify the difference between companies that generate a price premium and those that do not.

The volume of timber handled has increased significantly since FY 2017 compared to FY 2016, when the Tama Roundwood Market Center began handling certified timber. This increase was due to the Olympic and Paralympic Games. In addition, if much of the wood handled at the center becomes certified, as a buyer, if you want wood, you will buy it regardless of whether it is certified or not. The likely reason why there are more SGECs than FSCs for each type of forest certification is that it is easier for forest owners to obtain SGECs than FSCs. The SGECs can be regarded as international certification through mutual recognition with PEFCs, so there is less of a difference between FSCs and SGECs for the average buyer.

\section{Conclusions}

To summarize, this paper analyzed the volume and price of raw wood handled by the Tama Roundwood Market Center in Tokyo and found that:

- $\quad$ The handling volume of logs increased due to the regeneration cutting project.

- There was no price premium for Tama-certified raw wood under the local certification scheme.

- $\quad$ There were no price premiums for either FSC- or SGEC-certified raw wood.

Price premiums for forest certifications are necessary for ongoing sustainable forest management, and there is a need to increase consumer awareness on forest certifications and to differentiate quality certifications further.

While the SDGs are in the spotlight, the role of forest certification schemes as proof of sustainable forest management is significant. Forest enterprises in Tokyo are subsidized by the Tokyo Metropolitan Government to pay for certification, so there is no economic burden on forest enterprises. However, if there is no price premium for raw wood for forest owners who do not receive subsidies, obtaining certifications will be an economic burden. Although there are many forest enterprises that are willing to continue forest certifications, the reality is that financial support is needed [45]. A price premium for raw wood is essential for obtaining and continuing forest certification without subsidies. 
The majority of those who recognized the meaning of forest certification gave positive feedback [46]. Action is required to strengthen the promotion of forest certification systems to consumers. In the future, with an increasing number of certified logs being handled, a price premium through further differentiation will require not only a certification of origin and environmental friendliness, but also quality evaluations based on indicators such as damage during drilling, rot, scratches, bends, cracks, knots, date of cutting, and storage period through the development of a new scheme for evaluating the quality of raw wood.

This study is based on data from the roundwood market in Tokyo, and does not show a trend for Japan as a whole. Therefore, an analysis of the roundwood market on a nationwide basis is required. However, it is possible that the results for Tokyo, a global economic city, show not only a trend for Japan as a whole but also a global trend.

Author Contributions: Conceptualization, K.S.; methodology, K.S.; investigation, S.K. and K.S.; resources, S.K.; data curation, S.K.; writing-original draft preparation, K.S. and S.K.; writingreview and editing, K.S.; supervision, K.S. Authorship must be limited to those who have contributed substantially to the work reported. All authors have read and agreed to the published version of the manuscript.

Funding: This research was supported by an individual research grant from the College of Bioresource Sciences, Nihon University.

Institutional Review Board Statement: Not applicable.

Informed Consent Statement: Not applicable.

Acknowledgments: We acknowledge the help of Kiyoshi Mitani, who provided the data on the amount of raw wood handled at the Tama Roundwood Market Center that we used in this study.

Conflicts of Interest: The authors declare no conflict of interests.

\section{References}

1. Ozinga, S. Behind the Logo: An Environmental and Social Assessment of Forest Certification Schemes.; Fern: Gloucestershire, UK, 2001; p. 62.

2. What is PEFC? History. Available online: https://www.pefc.org/discover-pefc/what-is-pefc/history (accessed on 14 July 2020).

3. Hayami, T. Why and how I challenged the first FSC certification in Japan. Jpn. J. For. Plan. 2000, 34, 127-130. (In Japanese) [CrossRef]

4. Forestry Agency of Japan (Ed.) Annual Report on Trends in Forest and Forestry in Japan: Fiscal Year 2020; National Forest Development and Extension Association: Tokyo, Japan, 2019; p. 279, ISBN 978-4-88138-375-9. (In Japanese)

5. Takahashi, T. Analysis of diffusion patterns of forest certification in Japan. Appl. For. Sci. 2011, 20, 1-9. (In Japanese with English Abstract) [CrossRef]

6. Iwamoto, Y.; Shiga, K. Development of SGEC forest certification and response of forestry enterprises. In Framework Formation and Forestry Labor Issues of Regional Forest Management; Shiga, K., Fujikake, I., Koroki, K., Eds.; Japan Forestry Investigation Committee: Tokyo, Japan, 2011; pp. 161-194; ISBN 978-4-88965-205-5. (In Japanese)

7. Sakamoto, T.; Shiba, M. The effects of forest certification scheme on forest management practice: Case study in the result of SGEC and FSC forest certification assessment in Japan. Appl. For. Sci. 2009, 18, 9-14. (In Japanese with English Abstract) [CrossRef]

8. Sugiura, K.; Konohira, Y. Features of evaluations of FSC certification bodies: Analysis of certification results of 17 Japanese forests. J. Jpn. For. Soc. 2005, 87, 241-246. (In Japanese with English Abstract) [CrossRef]

9. Sugiura, K.; Yoshioka, T.; Inoue, K. Effects of acquiring FSC forest management certification for Japanese enterprises using SmartWood audits. J. For. Res. 2012, 23, 165-172. [CrossRef]

10. Sugiura, K.; Sonohara, W. Trends in evaluations of Sustainable Green Ecosystem Council (SGEC) certified forests in Japan. Small-scale For. 2017, 16, 37-51. [CrossRef]

11. Tomimura, S. The Japanese forest and forestry course: Findings from the FSC forest certification. Mizu-joho 2003, $23,13-17$. (In Japanese)

12. Sugiura, K.; Yoshioka, T.; Inoue, K. Improvement of forest management in Asia through assessment of Forest Stewardship Council certification. For. Sci. Technol. 2013, 9, 164-170. [CrossRef]

13. Overview of global trends in FSC certificates. Available online: http:/ / pubs.iied.org/pdfs/G00411.pdf (accessed on 17 July 2020).

14. Rametsteiner, E.; Simula, M. Forest certification-an instrument to promote sustainable forest management? J. Environ. Manag. 2003, 67, 87-98. [CrossRef]

15. Spilsbury, J.M. The Sustainability of Forest Management: Assessing the Impact of CIFOR's Criteria and Indicators Research; CIFOR: Jawa Barat, Indonesia, 2005; p. 126; ISBN 979-3361-90-5. 
16. Newsom, D.; Bahn, V.; Cashore, B. Does forest certification matter? An analysis of operation-level changes required during the SmartWood certification process in the United States. For. Policy Econ. 2006, 9, 197-208. [CrossRef]

17. Hubbard, S.S.; Bowe, S.A. Environmentally certified wood products: Perspectives and experiences of primary wood manufacturers in Wisconsin. For. Prod. J. 2005, 55, 33-40.

18. Humphries, S.; Vlosky, R.P.; Carter, D. Certified wood-products merchants in the United States: A comparison between 1995 and 1998. For. Prod. J. 2001, 51, 32-38.

19. Owari, T.; Juslin, H.; Rummukainen, A.; Yoshimura, T. Strategies, functions, and benefits of forest certification in wood products marketing: Perspectives of Finnish suppliers. For. Policy Econ. 2006, 9, 380-391. [CrossRef]

20. Owari, T.; Sawanobori, Y. Analysis of the certified forest products market in Japan. Holz. Roh. Werkst. 2007, 65, 113-120. [CrossRef]

21. Nebel, G.; Quevedo, L.; Jacobsen, B.J.; Helles, F. Development and economic significance of forest certification: The case of FSC in Bolivia. For. Policy Econ. 2005, 7, 175-186. [CrossRef]

22. Kollert, W.; Lagan, P. Do certified tropical logs fetch a market premium?: A comparative price analysis from Sabah, Malaysia. For. Policy Econ. 2007, 9, 862-868. [CrossRef]

23. Forests and Forestry in Tokyo. Available online: https://www.sangyo-rodo.metro.tokyo.lg.jp/nourin/d96c04efdcaa5589b1486e3 6dc3cd6cf_1.pdf (accessed on 20 July 2020). (In Japanese)

24. Take Advantage of Japanese Cedar and Cypress in Your Mountains. Available online: https://www.tokyo-aff.or.jp/uploaded/ attachment/3581.pdf (accessed on 20 July 2020). (In Japanese)

25. Tama Wood Certification Scheme. Available online: http:/ /tamasanzai.tokyo-shinrinkyokai.com/ (accessed on 20 July 2020). (In Japanese)

26. Forest and Our Life No. 2. Available online: http://tokyo-shinrinkyokai.com/pdf/news_002.pdf (accessed on 20 July 2020). (In Japanese)

27. Forests and Forestry in Tokyo. Available online: https://www.sangyo-rodo.metro.tokyo.lg.jp/nourin/H29tokyoshinrin.pdf (accessed on 29 July 2020). (In Japanese)

28. List of Forest Certification Acquiring Entity as of November 9, 2017. Available online: https://tokyogrown.jp/learning/forestry/ pdf/forestry_authentication.pdf (accessed on 31 July 2020). (In Japanese)

29. Masters, M.; Tikina, A.; Larson, B. Forest certification audit results as potential changes in forest management in Canada. Forest. Chron. 2010, 86, 455-460. [CrossRef]

30. Yoshidomi, R.; Sugiura, K.; Yoshioka, T.; Inoue, K. Effects of final cutting as a preventive measure of pollinosis on the trade of logs originated from Tama region and the regional forestry. J. Jpn. For. Eng. Soc. 2010, 25, 103-110. (In Japanese) [CrossRef]

31. Kameyama, S.; Yoshioka, T.; Inoue, K. Effects of final cutting project as a preventive measure of pollinosis from handling volume of Tama Timber Center. J. Jpn. For. Eng. Soc. 2018, 33, 53-58. (In Japanese) [CrossRef]

32. Kameyama, S.; Sugiura, K. Effects of promotion business for sustainable forest management on timber distribution in the Tama area of Tokyo. Kanto J. For. Res. 2020, 71, 17-20. (In Japanese with English Abstract)

33. Toriumi, H. Research on distribution of regional raw wood: Raw wood price and raw wood usage survey at Tama Roundwood Market Center. Tokyo For. Res. Inst. Annu. Rep. 2003 FY 2004, 11-14. (In Japanese)

34. Matsuura, T. Pest species entering Japanese cedar log and countermeasures against damage. Research report in Toyama Pref. Agri. For. Fish. Res. Cntr. 2017, 1-4. (In Japanese)

35. Toriumi, H.; Okegawa, H. Research on distribution of regional raw wood: Trends in raw wood prices at the Tama Roundwood Market Center. Tokyo For. Res. Inst. Annu. Rep. 2003 FY 2003, 11-14. (In Japanese)

36. Tikina, A.V.; Innes, J.L. A framework for assessing the effectiveness of forest certification. Can. J. For. Res. 2008, 38, 1357-1365. [CrossRef]

37. Awareness and Intention Survey on Circulation Utilization of Forest Resources. Available online: http://www.maff.go.jp/j/ finding/mind/pdf/sinrin_27.pdf (accessed on 13 February 2018). (In Japanese)

38. Ikuta, T. Consideration about green market and product brand. Econ. Rev. 2002, 6, 52-72. (In Japanese; English Abstract)

39. Doremus, J. Unintended impacts from forest certification: Evidence from indigenous Aka households in Congo. Ecol. Econom. 2019, 106378. [CrossRef]

40. Galati, A.; Gianguzzi, G.; Tinervia, S.; Crescimanno, M.; La Mela Veca, D.S. Motivations, adoption and impact of voluntary environmental certification in the Italian Forest based industry: The case of the FSC standard. For. Policy Econ. 2017, 169-176. [CrossRef]

41. Nakamura, M.; Takahashi, T.; Vertinsky, I. Why Japanese firms choose to certify: A study of managerial responses to environmental issues. J. Environ. Econ. Manag. 2001, 23-52. [CrossRef]

42. Ota, I. Ecology-oriented house builders and FSC-certified domestic timber in Japan. Small-scale For. 2010, 9, 81-92. [CrossRef]

43. Sugiura, K.; Oki, Y. Reasons for choosing Forest Stewardship Council (FSC) and Sustainable Green Ecosystem Council (SGEC) schemes and the effects of certification acquisition by forestry enterprises in Japan. Forests 2018, 9, 173. [CrossRef]

44. Gubbage, F.; Diaz, D.; Yapura, P.; Dube, F. Impacts of forest management certification in Argentina and Chile. For. policy Econ. 2010, 12, 497-504. [CrossRef] 
45. Hashimoto, R.; Kimura, Y.; Kobayashi, M.; Mitani, K. The spread and problems of Forest Certification in Tama Lumber. J. Jpn. For. Eng. Soc. 2020, 35, 39-44. (In Japanese) [CrossRef]

46. Ota, I.; Kamakura, M. An empirical study on the price premium of certified wood products. J. For. Eco. 2016, 62, 42-48. (In Japanese with English Abstract) [CrossRef] 